\title{
Effect of including liquid vinasse in the diet of rabbits on growth performance
}

\section{Maria Cristina de Oliveira ${ }^{1}$, Diones Montes da Silva ${ }^{2}$, Celiza de Almeida Faleiros e Rodrigues Carvalho², Mirlley Ferreira Alves², Daisa Mirelle Borges Dias², Poliana Carneiro Martins², Nadielli Pereira Bonifácio ${ }^{2}$, Marcos Aurélio Proto de Souza Júnior ${ }^{3}$}

\footnotetext{
${ }^{1}$ Faculdade de Medicina Veterinária - Universidade de Rio Verde. Caixa Postal 104, Rio Verde, GO, Brazil.

2 Estudante da Faculdade de Medicina Veterinária - Universidade de Rio Verde, Rio Verde, GO, Brazil.

${ }^{3}$ Agrodefesa, Rio Verde, GO, Brazil.
}

\begin{abstract}
The effects of liquid vinasse (LV) in the diet for growing rabbits on performance, carcass yield and intestinal morphometry were assessed. Eighty New Zealand white rabbits were used in a randomized block design with five treatments (LV inclusion at 0,25,50,75 and $100 \mathrm{~g} / \mathrm{kg}$ diet) and four replications. There was no effect of the treatment on final weight, daily weight gain, mortality rate and carcass yield characteristics. The daily intakes of feed, dry matter, crude protein and energy and feed conversion decreased linearly with increase in LV in the diet. Including LV affected the duodenum crypt depth and the ilium villus perimeter and height linearly and affected the duodenum villus perimeter, height and the absorption surfaces and ilium crypt depth and absorption surface quadratically. There was no effect of including LV on jejunum morphometry. Vinasse can be used to feed growing rabbits at up to $87.8 \mathrm{~g}$ per kilogram of diet.
\end{abstract}

Key Words: alcohol production residue, animal feeding, vinasse

\section{Introduction}

Sugarcane and ethanol production in the state of Goias, Brazil, in the 2008/2009 growing season, was 29,486,508 tons and 1,726,080 liters, respectively (Unica, 2009a,b). Twelve to 20 liters of vinasse are produced per liter of ethanol produced (Cazetta \& Celligoi, 2006). Vinasse has the greatest polluting load of the effluents produced by alcohol distilleries because it presents oxygen biochemistry demand ranging from 20,000 to $30,000 \mathrm{mg} / \mathrm{L}$ vinasse (Leite, 1999).

The word vinasse is derived from the Latin vinacaeus, originally known as fermented wine. Its use has been reported in various tropical countries and in Europe as an additive or food supplement for ruminants and nonruminants. Vinasse has approximately $930 \mathrm{~g} / \mathrm{kg}$ water and $17 \mathrm{~g} / \mathrm{kg}$ solid compounds, dark color, sweet smell, acid $\mathrm{pH}$ and high salt levels. This effluent has high concentrations of potassium, calcium, magnesium, sulfur, nitrogen (Hidalgo et al., 2009) and also yeasts (403.56 mg/L) (Souza, 2007).

The average composition of vinasse, on a dry matter basis, is $121 \mathrm{~g} / \mathrm{kg}$ crude protein, $66 \mathrm{~g} / \mathrm{kg}$ mineral matter, $5 \mathrm{~g} / \mathrm{kg}$ calcium, $2.4 \mathrm{~g} / \mathrm{kg}$ phosphorus, $16 \mathrm{~g} / \mathrm{kg}$ potassium, $0.8 \mathrm{~g} / \mathrm{kg}$ sodium, and $1.08 \mathrm{~g} / 100 \mathrm{~mL}$ lysine (Hidalgo et al., 2009) and according to Albers (2009), vinasse, in natura, presents the following characteristics: $\mathrm{pH} 4.4$ to $4.6 ; 470$ to $710 \mathrm{mg} / \mathrm{L}$ nitrogen, 9 to $200 \mathrm{mg} / \mathrm{L}$ phosphorus; 3340 to $4600 \mathrm{mg} / \mathrm{L}$ potassium; 1330 to $4570 \mathrm{mg} / \mathrm{L}$ calcium and 580 to $700 \mathrm{mg} / \mathrm{L}$ magnesium.

According to Hidalgo et al. (2009), vinasse has been used in the liquid form in animal feeding as an additive because of its probiotic properties, as a carrier in premixes, palatabilizer or promoter of sexual maturity and reproduction. Its use as an additive has generally resulted in better feed conversion and increased body weight and growth because of the presence of the organic acids, which improve nutrient use, digestion, vitamin $\mathrm{D}$ synthesis and vitamin $\mathrm{C}$ and mineral absorption, which facilitate the food metabolism.

Animal feeding accounts for almost $70 \%$ of production costs, so any alternative feedstuff that might reduce costs are useful to the producer because this increases his or her profit.

The objective of the present research was to assess the effects of including levels of vinasse (LV) in a diet for growing rabbits on the productive performance and intestinal morphometry.

\section{Material and Methods}

The experiment was carried out at the Rabbit Rearing Sector at the Universidade de Rio Verde, Goiás, Brazil. 
Eighty male and female New Zealand white rabbits, weaned at 35 days, were used. A randomized block design with five treatments and four replications was used. The treatments consisted of LV inclusion levels (Table 1) in the commercial rabbit diet (Table 1), based on weight. The inclusion levels were $0,25,50,75$ and $100 \mathrm{~g} / \mathrm{kg}$, based on the weight of the commercial diet ingested daily.

Each rabbit received 70, 90, 110, 130, 140 and $150 \mathrm{~g}$ diet per day, in the first, second, third, fourth, fifth and sixth weeks, respectively. The percentages relative to the LV were subtracted from this quantity. The vinasse was weighed, sprayed on the diet and then mixed into it for total incorporation in the pellets.

The rabbits were housed in a masonry barn, in metal cages with drinker and feeder. The water and pelleted commercial diet, mixed with LV, were supplied freely.

The animals were weighed at the beginning and end of the experimental period, when the rabbits reached 77 days of age, to obtain weight gain and the diets were weighed daily to calculate the diet intake and feed conversion. Mortality rate was also determined.

After the final weighing, the animals were feed-deprived for 12 hours and then weighed again to obtain the weight at slaughter, which served as reference to calculate the carcass yield. After evisceration, head and paws were removed, leaving only the carcass, which was then weighed. The edible viscera were also weighed and their relative weights were calculated in relation to the slaughter weight.

Small intestine samples of approximately $3 \mathrm{~cm}$ were collected from the duodenum (10 $\mathrm{m}$ from the stomach), the jejunum (in the middle region of the small intestine) and the ileum (at $10 \mathrm{~cm}$ from the ileocecal junction). The samples were fixed in $10 \%$ formaldehyde for 24 hours and fragments were processed for blocking in paraffin. Serial $5 \mu \mathrm{m}$ sections were made in each fragment and stained with hematoxylin and eosin. Thirty readings were taken per fragment for villus height, perimeter and width, crypt depth, the thickness of the mucous and muscular tunics. The absorption surface (AS) is was calculated by the formula:
AS $\left(\mathrm{mm}^{2}\right)=$ villus height $(\mathrm{mm}) \mathrm{x}$ width at $50 \%$ of the villus height (mm)

The economic viability was calculated considering the average sale values of live rabbits for slaughter, slaughtered rabbit and the price of the diet consumed. The gross margin was obtained by the difference between the gross profit (live animal weight $\times$ price $\mathrm{kg}$ live animal or carcass weight $\times$ price $\mathrm{kg}$ slaughtered animal) and the diet cost (weight of diet consumed $\times$ price $\mathrm{kg}$ diet) (Oliveira \& Lui, 2006). The price of one kilogram of live animal was $\mathrm{R} \$ 5.00$, of slaughtered animal, $\mathrm{R} \$ 12.00$, and the diet cost $\mathrm{R} \$ 0.92 \mathrm{~kg}$. The rabbit prices were obtained from the Brazilian Scientific Association of Rabbit Breeders on 12/01/2012.

The results were subjected to analysis of variance and polynomial regression using software SAEG (System for Statistical Analyses, version 9.1) and $\alpha=0.05$ was adopted.

\section{Results and Discussion}

There was no effect $(\mathrm{P}<0.05)$ of the treatments on final weight, daily weight gain and mortality rate but the daily intakes of feed, dry matter, crude protein and energy decreased linearly $(\mathrm{P}<0.05)$ with increased LV levels in the diet. Reduction in diet intake without reduction in weight gain resulted in better $(\mathrm{P}<0.05)$ feed conversion and these values decreased linearly with increase in LV (Table 2).

The reduction in feed and nutrient intake was probably due to the high water content in LV, which improved the action of the digestive enzymes and increased the quantity of nutrients available for absorption (Luis e Silva et al., 2011). Furthermore, the organic acids in LV, including fumaric acid (Ryznar-Luty et al., 2008), improved nutrient use in the small intestine, inhibited bacterial proliferation and decreased the host-bacteria nutrient competition (Roura \& Javierre, 2008), which resulted in better feed conversion. Vinasse also kept the intestinal flora in balance, preventing propagation of intestinal pathogens that could negatively influence the total production (Hidalgo et al., 2009).

Table 1 - Nutritional levels of the commercial diet supplemented with increasing levels of liquid vinasse (LV) and LV based on dry matter

\begin{tabular}{|c|c|c|c|c|c|c|}
\hline & \multicolumn{6}{|c|}{ LV level in the diets $(\mathrm{g} / \mathrm{kg})$} \\
\hline & 0 & 25 & 50 & 75 & 100 & Liquid vinasse \\
\hline Dry matter (g/kg) & 836 & 812 & 790 & 774 & 750 & 31.7 \\
\hline Crude protein $(\mathrm{g} / \mathrm{kg})$ & 214 & 214 & 214 & 218 & 218 & 86.3 \\
\hline Ether extract $(\mathrm{g} / \mathrm{kg})$ & 45.5 & 41.0 & 37.5 & 36.2 & 36.5 & - \\
\hline Mineral matter $(\mathrm{g} / \mathrm{kg})$ & 64.5 & 66.5 & 63.3 & 71.6 & 73.5 & 211.4 \\
\hline Calcium $(\mathrm{g} / \mathrm{kg})$ & 12.2 & 11.6 & 7.6 & 7.6 & 8.7 & 4.5 \\
\hline
\end{tabular}


Similar results were reported by Maertens et al. (1994), who used vinasse obtained from beetroot in the proportion of 40 and $80 \mathrm{~g} / \mathrm{kg}$ diet for 35 day-old rabbits and observed that the feed conversion was better at the highest inclusion level, and there was no effect on the other parameters.

There is little research on the use of vinasse in rabbit feeding, but according to Waliszewski et al. (1997), who used vinasse in chicken diet at the proportion of 40 and $60 \mathrm{~g} / \mathrm{kg}$, there was an improvement in the broiler performance with the dose of $40 \mathrm{~g} / \mathrm{kg}$. Similarly, Hidalgo et al. (2009) included $14 \mathrm{~mL}$ vinasse per bird/day in chicken diet, sprayed on the feed twice a day, and reported similar feed intake (3300 and $3309 \mathrm{~g} / \mathrm{bird}$ ) but with an extra $200 \mathrm{~g}$ gain in the bodyweight, better feed conversion (1.81 and 1.60) and a $2 \%$ increase in the survival rate and carcass weight.

Including LV in the diet did not affect $(\mathrm{P}<0.05)$ the carcass weight and yield and the edible viscera weight (Table 3).

Even with the presence of yeasts and nutrients in the vinasse such as vitamin $\mathrm{C}$, minerals and organic acids, substances that beneficially alter the intestinal flora and increase nutrient digestibility and absorption, there was no effect of including LV on the carcass and edible viscera parameters. Hidalgo et al. (2009) assessed the supply of
5,10 and $15 \mathrm{~mL} / \mathrm{d} / \mathrm{bird}$ in the initial, grower and finishing phases, respectively, for broiler chicks and reported that the carcass, breast and thigh yields increased along with vinasse use. According to the authors, LV can optimize nutrient use in poultry, improving the muscle disposition in the body, but this effect was not observed in the present experiment.

Including LV affected $(\mathrm{P}<0.05)$ the duodenum crypt depth (Table 4) and the ileum villus perimeter and height linearly (Table 5$)$ and affected $(\mathrm{P}<0.05)$ the villus perimeter and height and duodenum absorption surface and ilium crypt depth and absorption surface quadratically. Including LV in the diet brought no effect to the jejunum morphometry (Table 6).

In the duodenum, the smallest villus perimeter, height and surface absorption values were obtained with 33.4, 38.8 and $38.5 \mathrm{~g} \mathrm{LV}$ inclusion per $\mathrm{kg}$ of diet, respectively, and above these levels all the parameter values increased, showing a beneficial effect of LV on the intestinal morphometry.

In the ileum, the highest villus perimeter and height values were observed with $100 \mathrm{~g} / \mathrm{kg} \mathrm{LV}$ inclusion but the highest crypt depth and surface absorption values

Table 2 - Productive performance of rabbits at 77 days of age fed diets containing levels of vinasse

\begin{tabular}{|c|c|c|c|c|c|c|c|c|c|c|}
\hline \multirow{2}{*}{ Parameters } & \multicolumn{5}{|c|}{ Liquid vinasse levels (g/kg) } & \multirow{2}{*}{$\begin{array}{l}\text { CV } \\
(\%)\end{array}$} & \multicolumn{4}{|c|}{ P-value } \\
\hline & 0 & 25 & 50 & 75 & 100 & & Linear & Quadratic & Cubic & Fourth level \\
\hline Final weight $(\mathrm{g})$ & 2092 & 2081 & 2005 & 2111 & 1961 & 5.0 & 0.1888 & 0.3872 & 0.3804 & 0.2468 \\
\hline Daily weight gain (g/d) & 37.17 & 36.82 & 34.83 & 37.49 & 33.84 & 5.9 & 0.1171 & 0.2755 & 0.2500 & 0.1125 \\
\hline Daily feed intake $(\mathrm{g} / \mathrm{d})^{1}$ & 133 & 131 & 111 & 111 & 108 & 4.3 & 0.0061 & 0.0560 & 0.0615 & 0.1011 \\
\hline Daily dry matter intake $(\mathrm{g} / \mathrm{d})^{2}$ & 112 & 106 & 88 & 86 & 81 & 5.5 & 0.0013 & 0.0714 & 0.0845 & 0.0981 \\
\hline Daily crude protein intake $(\mathrm{g} / \mathrm{d})^{3}$ & 23.90 & 22.85 & 18.75 & 18.75 & 17.75 & 4.5 & 0.0016 & 0.0523 & 0.0740 & 0.1170 \\
\hline Daily gross energy intake $(\mathrm{kcal} / \mathrm{d})^{4}$ & 450 & 436 & 355 & 352 & 331 & 4.1 & 0.0024 & 0.0609 & 0.0672 & 0.0874 \\
\hline Feed:gain ratio in natural matter ${ }^{5}$ & 3.58 & 3.55 & 3.19 & 2.98 & 3.21 & 5.0 & 0.0344 & 0.0694 & 0.0685 & 0.1418 \\
\hline Feed:gain ratio in dry matter ${ }^{6}$ & 2.99 & 2.88 & 2.52 & 2.30 & 2.41 & 5.9 & 0.0011 & 0.0533 & 0.0733 & 0.1521 \\
\hline Survival rate $(\%)$ & 100.00 & 100.00 & 100.00 & 87.50 & 100.00 & 3.2 & 0.2472 & 0.2853 & 0.0891 & 0.1510 \\
\hline
\end{tabular}

$\mathrm{CV}$ - coefficient of variation

${ }^{1}$ Linear effect $\left(\hat{\mathrm{Y}}=133.06-2.80 \mathrm{x}, \mathrm{r}^{2}=0.35\right)$

${ }^{2}$ Linear effect $\left(\hat{Y}=110.88-3.2405 x, r^{2}=0.38\right)$.

${ }^{3}$ Linear effect $\left(\hat{\mathrm{Y}}=23.68-0.6564 \mathrm{x}, \mathrm{r}^{2}=0.34\right)$.

${ }^{4}$ Linear effect $\left(\hat{Y}=539.404-11.106 x, r^{2}=0.33\right)$.

${ }^{5}$ Linear effect $\left(\hat{\mathrm{Y}}=3.56-0.052 \mathrm{x}, \mathrm{r}^{2}=0.64\right)$.

${ }^{6}$ Linear effect $\left(\hat{\mathrm{Y}}=2.97-0.0698 \mathrm{x}, \mathrm{r}^{2}=0.45\right)$.

Table 3 - Carcass weight and yield for edible viscera from 77-day-old rabbits fed diets containing vinasse

\begin{tabular}{|c|c|c|c|c|c|c|c|c|c|c|}
\hline \multirow{2}{*}{ Parameters } & \multicolumn{5}{|c|}{ Liquid vinasse levels (g/kg) } & \multirow{2}{*}{$\begin{array}{l}\text { CV } \\
(\%)\end{array}$} & \multicolumn{4}{|c|}{ P-value } \\
\hline & 0 & 25 & 50 & 75 & 100 & & Linear & Quadratic & Cubic & Fourth level \\
\hline Carcass weight (g) & 1130 & 1087 & 1125 & 1137 & 955 & 5.2 & 0.3800 & 0.4400 & 0.5000 & 0.4479 \\
\hline Carcass yield (g/kg body weight) & 520.0 & 531.5 & 541.9 & 546.8 & 512.7 & 4.1 & 0.4241 & 0.4603 & 0.4441 & 0.4168 \\
\hline \multicolumn{11}{|c|}{ Relative weight ( $\mathrm{g} / \mathrm{kg}$ body weight) } \\
\hline Heart & 4.1 & 4.1 & 4.4 & 4.2 & 4.4 & 4.6 & 0.1750 & 0.1321 & 0.1214 & 0.1162 \\
\hline Liver & 48.8 & 42.9 & 42.6 & 45.9 & 45.2 & 6.3 & 0.3430 & 0.4832 & 0.4526 & 0.4199 \\
\hline Kidneys & 12.9 & 12.9 & 11.5 & 12.8 & 12.5 & 4.2 & 0.1557 & 0.1028 & 0.0914 & 0.0891 \\
\hline
\end{tabular}

$\mathrm{CV}$ - coefficient of variation. 
Table 4 - Duodenum morphometry of 77-day-old rabbits fed diets containing levels of vinasse

\begin{tabular}{|c|c|c|c|c|c|c|c|c|c|c|}
\hline \multirow{2}{*}{ Parameters } & \multicolumn{5}{|c|}{ Liquid vinasse levels (g/kg) } & \multirow{2}{*}{$\begin{array}{l}\text { CV } \\
(\%)\end{array}$} & \multicolumn{4}{|c|}{ P-value } \\
\hline & 0 & 25 & 50 & 75 & 100 & & Linear & Quadratic & Cubic & Fourth level \\
\hline Villus perimeter $(\mu \mathrm{m})^{1}$ & 1681 & 1481 & 1539 & 1799 & 1825 & 7.7 & 0.0270 & 0.0075 & 0.0518 & 0.0620 \\
\hline Villus height $(\mu \mathrm{m})^{2}$ & 834 & 738 & 771 & 889 & 898 & 8.2 & 0.0420 & 0.0158 & 0.0553 & 0.0529 \\
\hline Crypt depth $(\mu \mathrm{m})^{3}$ & 67 & 83 & 87 & 90 & 91 & 8.3 & 0.0046 & 0.05992 & 0.0643 & 0.0526 \\
\hline Villus height/crypt depth ratio & 12.36 & 9.06 & 9.67 & 10.15 & 9.86 & 7.1 & 0.2020 & 0.1047 & 0.0611 & 0.0529 \\
\hline Absorption surface $\left(\mathrm{mm}^{2}\right)^{4}$ & 0.089 & 0.071 & 0.076 & 0.091 & 0.098 & 8.7 & 0.0435 & 0.0014 & 0.0572 & 0.0548 \\
\hline
\end{tabular}

$\mathrm{CV}$ - coefficient of variation.

${ }^{1}$ Quadratic effect $\left(\hat{\mathrm{Y}}=1636.51-48.878 \mathrm{x}+7.31 \mathrm{x}^{2} . \mathrm{R}^{2}=0.44\right)$.

${ }^{2}$ Quadratic effect $\left(\hat{\mathrm{Y}}=812.80-23.266 \mathrm{x}+3.44 \mathrm{x}^{2} . \mathrm{R}^{2}=0.38\right)$.

${ }^{3}$ Linear effect $\left(\hat{\mathrm{Y}}=72.21+2.1766 \mathrm{x}, \mathrm{r}^{2}=0.42\right)$.

${ }^{4}$ Quadratic effect $\left(\hat{\mathrm{Y}}=0.086-0.00494 \mathrm{x}+0.00064 \mathrm{x}^{2} . \mathrm{R}^{2}=0.54\right)$.

Table 5 - Jejunum morphometry of 77-day-old rabbits fed diets containing levels of vinasse

\begin{tabular}{|c|c|c|c|c|c|c|c|c|c|c|}
\hline \multirow{2}{*}{ Parameters } & \multicolumn{5}{|c|}{ Liquid vinasse levels (g/kg) } & \multirow{2}{*}{$\begin{array}{l}\text { CV } \\
(\%)\end{array}$} & \multicolumn{4}{|c|}{ P-value } \\
\hline & 0 & 25 & 50 & 75 & 100 & & Linear & Quadratic & Cubic & Fourth level \\
\hline Villus perimeter $(\mu \mathrm{m})$ & 1405 & 1503 & 1428 & 1546 & 1553 & 10.2 & 0.1178 & 0.1929 & 0.3342 & 0.2909 \\
\hline Villus height $(\mu \mathrm{m})$ & 683 & 746 & 659 & 751 & 774 & 9.9 & 0.0829 & 0.1449 & 0.2858 & 0.3124 \\
\hline Villus height/crypt depth ratio & 9.27 & 11.27 & 9.11 & 10.73 & 11.32 & 10.0 & 0.0810 & 0.1828 & 0.3273 & 0.2035 \\
\hline Absorption surface $\left(\mathrm{mm}^{2}\right)$ & 0.072 & 0.078 & 0.074 & 0.085 & 0.078 & 8.7 & 0.1203 & 0.3017 & 0.3010 & 0.4104 \\
\hline
\end{tabular}

$\mathrm{CV}$ - coefficient of variation.

Table 6 - Ileum morphometry of 77-day-old rabbits fed diets containing levels of vinasse

\begin{tabular}{|c|c|c|c|c|c|c|c|c|c|c|}
\hline \multirow{2}{*}{ Parameters } & \multicolumn{5}{|c|}{ Liquid vinasse levels (g/kg) } & \multirow{2}{*}{$\begin{array}{l}\text { CV } \\
(\%)\end{array}$} & \multicolumn{4}{|c|}{ P-value } \\
\hline & 0 & 25 & 50 & 75 & 100 & & Linear & Quadratic & Cubic & Fourth level \\
\hline Villus perimeter $(\mu \mathrm{m})^{1}$ & 953 & 1120 & 1132 & 1217 & 1225 & 3.9 & 0.0045 & 0.0266 & 0.0583 & 0.0646 \\
\hline Villus height $(\mu \mathrm{m})^{2}$ & 487 & 541 & 549 & 612 & 619 & 3.3 & 0.0008 & 0.0013 & 0.0611 & 0.1110 \\
\hline Crypt depth $(\mu \mathrm{m})^{3}$ & 82 & 90 & 93 & 110 & 85 & 8.0 & 0.5000 & 0.5000 & 0.3265 & 0.1686 \\
\hline Villus height/crypt depth ratio & 6.51 & 6.82 & 7.47 & 6.97 & 7.92 & 6.6 & 0.3255 & 0.5000 & 0.5000 & 0.5000 \\
\hline Absorption surface $\left(\mathrm{mm}^{2}\right)^{4}$ & 0.038 & 0.048 & 0.050 & 0.055 & 0.048 & 3.9 & 0.0075 & 0.0061 & 0.0775 & 0.0654 \\
\hline
\end{tabular}

$\mathrm{CV}$ - coefficient of variation.

${ }^{1}$ Linear effect $\left(\hat{\mathrm{Y}}=1009.88+24.475 \mathrm{x}, \mathrm{r}^{2}=0.72\right)$.

${ }^{2}$ Linear effect $\left(\hat{\mathrm{Y}}=492.946+13.294 \mathrm{x}, \mathrm{r}^{2}=0.80\right)$

${ }^{3}$ Quadratic effect $\left(\hat{\mathrm{Y}}=68.61+5.062 \mathrm{x}-0.288 \mathrm{x}^{2} . \mathrm{R}^{2}=0.42\right)$

${ }^{4}$ Quadratic effect $\left(\hat{Y}=0.039+0.00316 x-0.0002 x^{2} . R^{2}=0.49\right)$.

were obtained with 87.8 and $79.0 \mathrm{~g} / \mathrm{kg} \mathrm{LV}$ inclusion, respectively.

The better development of the intestinal mucosa tissues in rabbits fed LV may have been due to the low $\mathrm{pH}$ value of the vinasse and the diets with LV levels over $75 \mathrm{~g} / \mathrm{kg}$ (5.98 and 5.89). Low $\mathrm{pH}$ favors the presence of saprophytic intestinal flora and prevents the establishment of pathogenic bacteria that might damage the intestinal mucosa by colonization and toxin production. Acid substances, such as LV, have been used as additives in animal feeding also because they increase energy and crude protein digestibility, mineral absorption and retention (Diebold \& Eidelsburger, 2006).

Furthermore, according to Hidalgo et al. (2009), the few fibers in LV are represented by glucan and mannan, present in the yeast walls, also having a beneficial effect on protecting the intestinal mucosa (Morales, 2007; Oliveira et al., 2008).
These substances may be used as substrate by beneficial bacteria with later short-chain fatty-acid production that helps reduce the $\mathrm{pH}$ of the microenvironment of the brush border even further and decreases pathogen adhesion (Oliveira et al., 2008). Mannan fermentation may also increase the mucosa thickness, number of epithelial cells per crypt and the venous blood flow (Zafar et al., 2004).

Liquid vinasse has a good amino acid and mineral profile (Hidalgo et al., 2009) that may have collaborated with cell proliferation and integrity of the intestinal mucosa.

Considering the gross margin resulting from the sale of live rabbits to the slaughterhouse and rabbits already slaughtered for sale, the best values were obtained with inclusion of $75 \mathrm{LV} \mathrm{g} / \mathrm{kg}$, which were respectively 8.79 and $7.12 \%$ greater than the values obtained with the treatment without vinasse (Table 7). 
Table 7 - Economic viability of the productive performance of growing rabbits fed diets containing vinasse

\begin{tabular}{|c|c|c|c|c|}
\hline \multirow{2}{*}{$\begin{array}{l}\text { Vinasse level } \\
(\mathrm{g} / \mathrm{kg})\end{array}$} & \multicolumn{4}{|c|}{ Sale of live rabbits for slaughter } \\
\hline & $\begin{array}{l}\text { Body weight } \\
\text { (kg) }\end{array}$ & $\begin{array}{c}\text { Live animal } \\
\text { price }(\mathrm{R} \$)\end{array}$ & $\begin{array}{c}\text { Cost of diet } \\
\text { ingested }(\mathrm{R} \$)\end{array}$ & $\begin{array}{c}\text { Gross margin } \\
(\mathrm{R} \$)\end{array}$ \\
\hline 0 & 2.092 & 10.46 & 5.14 & 5.32 \\
\hline 25 & 2.081 & 10.40 & 5.06 & 5.34 \\
\hline 50 & 2.005 & 10.02 & 4.28 & 5.74 \\
\hline 75 & 2.111 & 10.55 & 4.28 & 6.27 \\
\hline \multirow[t]{3}{*}{100} & 1.961 & 9.80 & 4.17 & 5.52 \\
\hline & \multicolumn{4}{|c|}{ Sale of slaughtered rabbits } \\
\hline & $\begin{array}{c}\text { Carcass } \\
\text { weight }(\mathrm{kg})\end{array}$ & $\begin{array}{c}\text { Carcass price } \\
(\mathrm{R} \$)\end{array}$ & $\begin{array}{c}\text { Cost of diet } \\
\text { ingested }(\mathrm{R} \$)\end{array}$ & $\begin{array}{c}\text { Gross margin } \\
(\mathrm{R} \$)\end{array}$ \\
\hline 0 & 1.130 & 13.56 & 5.14 & 8.42 \\
\hline 25 & 1.087 & 13.04 & 5.06 & 7.98 \\
\hline 50 & 1.125 & 13.50 & 4.28 & 9.22 \\
\hline 75 & 1.137 & 13.64 & 4.28 & 9.36 \\
\hline 100 & 0.955 & 11.46 & 4.17 & 7.29 \\
\hline
\end{tabular}

Sarria \& Preston (1992) used concentrated vinasse for finishing pigs and observed that its use resulted in 5\% faster growth and reduced the diet price by $15 \%$, as was also observed in the present experiment regarding the diet cost.

\section{Conclusions}

In natura liquid vinasse can be used to feed growing rabbits at $87.8 \mathrm{~g}$ per kilogram of diet.

\section{Acknowledgements}

The authors thank Usina Santa Helena de Açúcar e Álcool S/A (Santa Helena Sugar and Alcohol Mill) for donating the vinasse used in this research.

\section{References}

ALBERS, M. Concentração de vinhaça. Tecnologias, equipamentos e sua integração energética numa destilaria. In: CONGRESSO INTERNO DE INICIAÇÃO CIENTÍFICA DA UNICAMP, 17., 2009, Campinas. Anais... Campinas: UNICAMP, 2009. p.280.

CAZETTA, M.L.; CELligOI, M.A.P.C. Estudo de diferentes combinações de melaço/vinhaça como substrato para produção de proteínas e lipídios por microrganismos. Semina: Ciências Exatas e Tecnológicas, v.27, p.3-10, 2006.

DIEBOLD, G.; EIDELSBURGER, U. Acidification of diets as na alternative to antibiotic growth promoter. In: BARUG, D.; JONG, J.; KIES, A.K. et al. (Eds.) Antimicrobial growth promoter. The Netherlands: Wageningen Academic Publishers, 2006. p.311-327.
HILDALGO, K.; RODRÍGUEZ, B.; VALDIVIÉ, M. et al. Utilización de la vinaza de destilería como aditivo para pollos en ceba. Revista Cubana de Ciência Agrícola, v.43, p.281-284, 2009.

LEITE, G.F. Avaliação econômica da adubação com vinhaça e da adubação mineral de soqueiras de cana-de-açúcar na Usina Monte Alegre Ltda - Monte Belo - MG. Revista da Universidade de Alfenas, v.5, p.189-191, 1999.

LUIS E SILVA, J.; LOPES, E.L.; NUNES, R.C. et al. Rações com diferentes níveis de inclusão de agua para suínos na fase de creche. Ciência Animal Brasileira, v.12, p.610-616, 2011.

MAERTENS, L.; DUCATELlE, R.; De GROOTE, G. Influence de l'incorporation alimentaire d'une vinasse a taux élevé de parois cellulaires de levure sur les performances du lapin en engraissement. World Rabbit Science, v.2, p.15-19, 1994.

MORALES, R. Las paredes celulares de leveduras de Saccharomyces cerevisiae: un aditivo natural capaz de mejorar la productividad y salud del pollo de engorde. 2007. 261p. Tese (Doctorado en Producción Animal) - Universidad Autónoma de Barcelona, Espanha.

OLIVEIRA, M.C.; LUI, J.F. Desempenho, características de carcaça e viabilidade econômica de coelhos sexados abatidos em diferentes idades. Arquivo Brasileiro de Medicina Veterinária e Zootecnia, v.58, n.6, p.1149-1155, 2006.

OLIVEIRA, M.C.; RODRIGUES, E.A.; MARQUES, R.H. et al. Performance and morphology of intestinal mucosa of broilers fed mannan-oligosaccharides and enzymes. Arquivo Brasileiro de Medicina Veterinária e Zootecnia, v.60, n.2, p.442-448, 2008.

ROURA, E.; JAVIERRE, J. A. Acidificantes sinérgicos en avicultura. Avicultura Profesional, n.26, p.18-21, 2008.

RYZNAR-LUTY, A.; KRZYWONOS, M.; CIBIS, E. et al. Aerobic biodegradation of vinasse by a mixed culture of bacteria of the genus Bacillus: optimization of temperature, $\mathrm{pH}$ and oxygenation state. Polish Journal of Environmental Studies, v.17, p.101-112, 2008.

SARRIA, P.; PRESTON, T.R. Reemplazo parcial del jugo de caña con vinaza y uso del grano de soya a cambio de torta en dietas de cerdos de engorda. Livestock Research and Rural Development, v.4, n.1, 1992. Available at: <http://www.lrrd.org/lrrd4/1/sarria.htm>. Accessed on: Fev. 6, 2012.

SOUZA, S.A.V. Métodos de utilização e aplicação de vinhaça. In: WORKSHOP - VINHAÇA, 2007, Jaboticabal. Anais... UNESP: Jaboticabal, 2007. Available at: <http://www.apta.sp.gov. br/cana/anexos/position_paper_sessao2_veronez.pdf.> Accessed on: Jan. 18, 2011.

UNIÃO DA INDÚSTRIA DE CANA-DE-AÇÚCAR - UNICA Produção de cana-de-açúcar do Brasil. 2009a. Available at: $<$ http:// www.unica.com.br/downloads/estatisticas/PROCESSAMENTO \%20DE\%20CANA\%20BRASIL.xls> Accessed on: Fev. 6, 2012.

UNIÃO DA INDÚSTRIA DE CANA-DE-AÇÚCAR - UNICA. Produção de etanol do Brasil. 2009b. Available at: <http://www. unica.com.br/downloads/estatisticas/PRODUÇÃO\%20DE\%20 ETANOL.xls $>$ Accessed on: Fev. 6, 2012.

WALISZEWSKI, K.N.; ROMERO, A.; PARDIO, V.T. Use of cane condensed molasses solubles in feeding broilers. Animal Feed Science and Technology, v.67, p.253-258, 1997.

ZAFAR, T.A.; WEAVER, C.M.; ZHAO, Y. et al. Nondigestible oligosaccharides increase calcium absorption and suppress bone resorption in ovariectomized rats. Journal of Nutrition, v.134, p.399-402, 2004. 